Review Article

\title{
HYPERTENSION IN RELATION TO IMMUNE SYSTEM AND WAY OF LIFE ALONG WITH TREATMENT
}

\author{
RAHUL MEHRA, AANCHAL, SHAINA KALSI, SURYA P. GAUTAM
}

Department of Pharmacology, CT Institute of Pharmaceutical Sciences, CT Group Institutions, Jalandhar, India 144020

Email: mehra6264@gmail.com

Received: 04 Aug 2021, Revised and Accepted: 10 Oct 2021

\begin{abstract}
The objective of the review is to explain the pathophysiology, different causes and various treatments involved in hypertension. This article discusses the disease's pathogenesis, etiology, diagnosis, and immunity. This review looks at the main significant epidemiological and clinical studies on the role of several lifestyle factors in hypertension development. This review examines the numerous mechanisms that cause hypertension in order to discover new treatments. In addition, it covers the many types of hypertension therapy. According to different studies, lifestyle habits may have an impact on blood pressure levels.

Moreover, the importance of chronic inflammation in hypertension and its repercussions has been confirmed in genetically engineered mice lacking components of innate and/or adaptive immunity. Immune cell depletion enhances endothelial function, lowers oxidative stress, lowers the vascular tone, and protects against renal interstitial infiltrates, salt retention, and kidney injury. Based on existing literature, there is strong evidence that lifestyle variables can affect blood pressure levels. Then, in hypertensive people, lifestyle changes can help by lowering overall cardiovascular risk and death from any cause. The involvement of immunity as a common thread in the hypertension processes of many organ systems.
\end{abstract}

Keywords: Hypertension, Immune system, Treatment

(C) 2021 The Authors. Published by Innovare Academic Sciences Pvt Ltd. This is an open access article under the CC BY license (https://creativecommons.org/licenses/by/4.0/)

DOI: https://dx.doi.org/10.22159/ijcpr.2021v13i6.1907 Journal homepage: https://innovareacademics.in/journals/index.php/ijcpr

\section{INTRODUCTION}

Hypertension has been recognized by the World Health Organization (WHO) as one of the most important risk factors for morbidity and mortality worldwide, accounting for roughly nine million deaths each year [1]. Essential hypertension (also known as primary hypertension or idiopathic hypertension) is the most prevalent kind of hypertension, affecting 95 percent of hypertensive patients [2-5] and is thought to be caused by a combination of environmental and hereditary factors. Essential hypertension is more common as people become older, and people who have moderately high blood pressure at a young age are more likely to acquire hypertension later in life, which causes them a lot of pain. Hypertension raises the risk of stroke, heart attack, and kidney failure [6]. Hypertension is linked to a higher risk of stroke (both ischemic and hemorrhagic), myocardial infarction, heart failure, chronic renal disease, peripheral vascular disease, cognitive impairment, and early mortality [7].

\section{Pathophysiology}

HTN is divided into two types: primary (or essential) HTN and secondary (or secondary) HTN, which account for 95 percent and $5 \%$ of hypertension patients, respectively [8]. Although the cause of essential HTN is unknown, it usually appears in the fifth or sixth decade of life, is frequently related with increasing salt intake and obesity, and has a strong link to family history, suggesting a hereditary predisposition [9]. Secondary HTN is accompanied by recognizable causes such as renal artery stenosis, chronic kidney disease, sleep apnea, and adrenal illnesses [8]. Multiple mechanisms involved in the maintenance of normal blood pressures are disrupted in both scenarios, and as a result, the sympathetic nervous system, renin-angiotensin-aldosterone system, endothelial function, sodium and water retention have all been extensively studied to determine mechanisms involved in the disease's development [10, $11]$.

\section{Etiology}

Blood pressure rises in youth have been linked to etiological factors linked to hypertension in adulthood. Intrauterine malnutrition, a family history of hypertension, obesity, especially excess abdominal fat, insulin resistance, high dietary sodium intakes, low dietary intakes of calcium, potassium, and magnesium, physical inactivity, high alcohol intakes, tobacco use, drug use (e. g., cocaine, ecstasy, anabolic steroids), emotional stress, diet pill use, and oral contraceptives are some of the factors linked to hypertension [2, 12, 13]. Inadequate nutrition may cause changes in the structure and metabolism of the foetus, increasing the risk of hypertension and other disorders later in life [14]. Hyperinsulinemia and insulin resistance are also linked to the development of hypertension, which can cause a slew of issues. Sodium sensitivity may be caused by high plasma insulin levels [2, 15]. Adequate intakes of potassium, calcium, and magnesium in the diet have been linked to lower blood pressure in children and adolescents. Intakes of potassium and calcium are below recommended limits, especially in adolescent females, but phosphorus and protein intakes, which accelerate calcium loss, are high [16]. Lack of physical activity has been shown to increase the risk of hypertension by 20 to 50 percent.

\section{Risk factors}

Individuals with a personal family history of hypertension are more likely to acquire hypertension [17]. Essential hypertension is four times more common in black people than in white people, progresses more quickly, and is often more severe in black patients, with a higher fatality rate. Salt restriction, like diuretic therapy, breaks the pathophysiologic sequence of events by lowering the extracellular fluid volume and blood pressure [18-21]. Obesity can increase the risk of hypertension by fivefold when compared to normal weight, and excess weight is responsible for up to two-thirds of hypertension cases. More than 85 percent of instances occur in those who have a BMI of more than 25 [22]. Another risk factor is salt sensitivity, which has attracted the most attention as an environmental issue. Sodium consumption affects around one-third of the essential hypertensive population [23]. Enhanced sodium ion concentration promotes $\mathrm{ADH}$ and thirst processes, resulting in increased water reabsorption in the kidneys, concentrated urine, and increased thirst with increased water consumption. In comparison, water flow between cells and the interstitium performs a small effect. The link between salt consumption and blood pressure is debatable. Although lowering sodium intake lowers 
blood pressure, the magnitude of the effect is insufficient to propose a widespread salt decrease [24].

\section{Treatment of hypertension}

Both non-pharmacologic and pharmacological treatments are used to treat hypertension. Whether or not there is a pre-existing CV, DM, or CKD influences the treatment selection. The 2017 AHA/ACC guideline advocated calculating the $10 \mathrm{y}$ risk of cardiovascular disease for patients with stage one hypertension who did not have these comorbidities. If the risk is less than $10 \%$, it is reasonable to undertake lifestyle changes on their own for 3 to 6 mo. Both lifestyle adjustment and medicine are suggested for stage 2 hypertension with pre-existing conditions such as diabetes mellitus (DM), CKD, and a $10 \mathrm{y}$ risk of $\mathrm{CV}$ event of $10 \%$ or higher.

\section{Non-pharmacological treatment}

Following are the non-pharmacologic way to treatment of hypertensions.

\section{Dietary salt restriction}

Dietary sodium consumption is limited to less than $1500 \mathrm{mg}$ per day $[25,26]$. Dietary salt restriction is related with a reduction of 5 to 10 $\mathrm{mmHg}$ in systolic blood pressure and 2 to $6 \mathrm{mmHg}$ in diastolic blood pressure in general hypertensive patients.

\section{Weight loss}

If a patient is overweight or obese, weight loss offers a clear advantage in terms of lowering blood pressure and reducing the number of recommended medicines [27]. Long-term weight loss studies have shown that a $10 \mathrm{~kg}$ weight loss is connected with a 6 $\mathrm{mmHg}$ systolic BP reduction and a $4.6 \mathrm{mmHg}$ diastolic BP reduction.

\section{Physical activity}

Regular aerobic exercise reduced systolic blood pressure by $4 \mathrm{mmHg}$ and diastolic blood pressure by $3 \mathrm{mmHg}$ on average. As a result, patients are advised to exercise for 90 to 150 min per week [28, 29]. As a result, all hypertension patients are recommended to exercise.

\section{High fiber and low-fat diet}

Dietary approach to halt hypertension (DASH) lowered systolic BP in hypertension patients by $11.4 \mathrm{mmHg}$ and diastolic BP by 5.5 $\mathrm{mmHg}$ by consuming a diet rich in fruits and vegetables, potassium, magnesium, calcium, high in low-fat diet and low in saturated fat [30]. A diet rich in fruits and vegetables not only lowers blood pressure but also improves endothelial function.

\section{Pharmacological treatment}

The 2017 ACC/AHA guideline advised that antihypertensive medication treatment be started with two first-line drugs from distinct classes, either separately or in a fixed-dose combination, with a target blood pressure of less than 130/80 mmHg [31].

\section{Initial drug selection}

Angiotensin-converting enzyme inhibitors (ACE inhibitors), angiotensin receptor blockers (ARBs), calcium channel blockers (CCBs), and thiazide type diuretics are the four types of antihypertensive medications, and each class of antihypertensive drugs reduces $\mathrm{CV}$ events [32]. Except for the major effect of beta blockers administered after MI reducing CAD event and calcium channel blockers reducing stroke, a meta-analysis of 147 randomised controlled trials of 464,000 patients with hypertension found that all major antihypertensive drug classes (diuretic, angiotensin-converting enzyme inhibitors, angiotensin receptor blockers, beta-blockers, and calcium channel blockers) reduced stroke [33]. The 2011 ACC/AHA hypertension guideline states that the efficacy, tolerability, existence of certain comorbities, and cost of antihypertensive medications in the treatment of adult hypertension are all factors to consider [34]. According to the 2011 ACC/AHA hypertension guidelines, diuretics, ACE inhibitors, ARBs, Beta blockers, and calcium channel blockers (CCBs) may be used to treat older patients with primary hypertension [34].

\section{Hypertension and diabetes mellitus}

ACE inhibitors or ARBs, CCBs, and thiazide diuretics should be used to treat patients with hypertension and diabetes [31, 35, 36]. Initial treatment with ACE inhibitors or ARBs in individuals with diabetes mellitus, hypertension, and chronic albuminuria $[31,37,38]$.

\section{Hypertension and pregnancy}

ACE inhibitors, ARBs, direct renin inhibitors, and atenolol should not be used by pregnant women with hypertension [31, 39-41]. In patients with hypertension during pregnancy, Methyldopa, Hydralazine, Nifedipine, and Labetalol are the drugs of choice [31, 42].

\section{Adverse pathophysiological effects of a wrong lifestyle \\ Salt intake}

The link between sodium consumption and extracellular fluid volume, arterial pressure, and the neuroendocrine system is well understood [43]. Experiments have shown that high salt intake causes an increase in left ventricular mass and intima-media thickness of major arteries, as well as severe proteinuria and renal fibrosis, regardless of arterial pressure [44-48]. Increases in circulating endothelin-1, a potent vasoconstrictor and proinflammatory peptide, are associated with an increase in sodium consumption $[49,50]$, whereas salt reduction is associated with improvements in artery flow-mediated dilation [51, 52]. The intrinsic action of sodium on microvascular vasomotion could then account for many of the renal and cardiovascular impairments seen in salt-sensitive hypertension individuals. In terms of the function of dietary salt intake in the development and treatment of hypertension, multiple prospective and outcome trials have shown that a lower salt intake is linked to a decreased risk of cardiovascular disease (CVD). The Inter-national Study of Salt and Blood Pressure (INTERSALT) and the Dietary Approach to Stop Hypertension trial (DASH), among other large cohort studies, found a substantial inverse connection between salt intake and both systolic and diastolic blood pressure. Multivariate analysis revealed that a sodium intake of 100 $\mathrm{mmol} /$ die resulted in an average increase of 3-6 mmHg in systolic and diastolic blood pressure of $3-6 \mathrm{mmHg}$ in the entire studied group in the INTERSALT investigation, an international multicentre trial [53].

\section{Cigarette smoke}

Because of the effects of several substances, particularly nicotine and carbon monoxide, cigarette smoking is widely regarded as a major cardiovascular risk factor for the heart and blood vessels [54, 55]. As a result of nicotine and carbon monoxide activity, functional and structural changes are frequently reported [56-59]. Some research [60-63] found that cigarette smokers had higher blood pressure and develop hypertension than non-smokers, implying that smoking has a negative effect on pressure values related to long-term exposure and the quantity of cigarettes smoked daily. A considerable improvement in systolic and diastolic pressure was recently reported in people who quit or reduced their tobacco intake [64].

\section{Alcohol intake}

The harmful effects of alcohol consumption on the liver, heart, pancreas, blood pressure, and other organ systems are well established. The acute effects of alcohol on blood pressure are complex and nonlinear, with pressor and depressor effects varying with time since ingestion [65]. Heavy drinking has long been linked to high blood pressure [66], and studies have found a linear association between alcohol intake, blood pressure levels, and the prevalence of hypertension in the general population [67-69]. Fuchs et al. found that alcohol misuse raises blood pressure, particularly systolic values and that this is more noticeable in black men, regardless of the type of drink consumed, whether red wine, white wine, beer, or liquor [70]. The role of moderate alcohol use, on the other hand, is still being contested. Furthermore, moderate alcohol use has been shown to enhance insulin sensitivity $[71,72]$ and is linked to a lower risk of developing type 2 diabetes when compared to abstention and heavy drinking [73].

\section{Physical activity}

Exercise training has been shown to have many hemodynamic and metabolic benefits, lowering overall cardiometabolic risk. In 
response to psychophysical stress, it lowers sympathetic responses and has an effect on the hypothalamic-pituitary-adrenal axis, resulting in lower cortisol levels, decreased cardiovascular reactivity, and faster cardiovascular recovery. Furthermore, physical activity causes a systemic adaptation of the artery wall, which may result in a reduction in peripheral resistance [74]. By boosting a number of pro-angiogenic factors, exercise training increases the number of capillaries for muscle fibre $[75,76]$. It has also been observed [77-79] that regular physical activity can prevent hypertension from developing, with sedentary normotensive persons having a relative risk of hypertension of 35 percent to 70 percent higher than their physically active peers. Furthermore, regular aerobic exercise training has been found to improve lipid profile, glycemic management, and obesity, lowering global cardiovascular risk and mortality [80, 81]. As a result, current European and American standards strongly urge moderate-intensity dynamic aerobic exercise for at least 30 min on 5-7 d each week [82, 83].

\section{Dietary patterns}

The impact of changing entire eating habits on blood pressure has been studied extensively. A variety of research suggests that, in addition to reducing alcohol and salt intake, adopting an optimal diet plays a role in lowering blood pressure values. Although calorie consumption is linked to body weight, obesity and overweight are linked to hypertension. Weight loss decreases blood pressure irrespective of achieving a desirable body weight, according to studies [84-86]. An average weight loss of $5.1 \mathrm{~kg}$ was linked to a drop in mean $4.4 \mathrm{mmHg}$ systolic and $3.6 \mathrm{mmHg}$ diastolic pressure in a meta-analysis of 25 trials [27].
Modest weight loss has also been shown to reduce hypertension in pre-hypertensive people and to make medication reduction and discontinuation easier [87-89]. Increased potassium intake has been shown to reduce blood pressure in both non-hypertensive and hypertensive participants $[30,90,91]$. This potassium hemodynamic effect appears to be more significant in people who consume a lot of sodium, and it could be linked to potassium-mediated sodium excretion in the distal renal tubule [30].

Omega-3 polyunsaturated fatty acids, which are mostly found in fish, have been shown to reduce the incidence of cardiovascular disease, implying that eating more fish is beneficial [92]. Omega-3 supplementation has also been shown to enhance arterial stiffness and endothelial function [93]. The ability of omega-3 fatty acid to incorporate into phospholipid membranes, partially replacing arachidonic acid as an initial substrate for the production of antiinflammatory eicosanoids, is thought to be the cause of these effects. Furthermore, some studies [94-96] found a small but significant reduction in blood pressure in patients taking omega-3 supplements. A meta-analysis that included 8 studies with over 56,000 participants recently found that normotensive people who consumed the most omega- 3 in their diet had a 27 percent lower chance of developing hypertension than those who consumed the least [97].

Increased antioxidant qualities have been linked to olive oil use. Extra virgin olive oil contains antioxidants, free radical scavengers, and enzyme modulators such as phenolic compounds, hydroxytyrosol, and oleuropein [98].

Table 1: Effects of a poor lifestyle on the body's pathophysiology

\begin{tabular}{|c|c|}
\hline Heavy alcohol intake & Liver, pancreas and cardiovascular damage \\
\hline \multirow[t]{5}{*}{ Excessive salt consumption } & Circulation volume has increased \\
\hline & Increased mass of the left ventricle \\
\hline & Thickness of the intima-media has increased \\
\hline & Plasma endothelin-1 levels are high. \\
\hline & Flow-mediated dilation is reduced. \\
\hline \multirow[t]{5}{*}{ Tobacco smoke } & Vasodilator function is impaired. \\
\hline & Endothelium-dependent vasodilation is reduced. \\
\hline & Nitric oxide availability is reduced. \\
\hline & Overstimulation of the sympathetic nervous system \\
\hline & Platelet aggregation has increased. \\
\hline \multirow[t]{3}{*}{ Physical exercise is being reduced. } & Cardiovascular reactivity is altered. \\
\hline & Stiffening of the arteries \\
\hline & Vasoconstrictor-vasodilator equilibrium is disrupted. \\
\hline \multirow[t]{4}{*}{ Dietary errors } & Obesity and being overweight \\
\hline & Antioxidant and anti-inflammatory activities are diminished. \\
\hline & Synthesis of nitric oxide is reduced. \\
\hline & Vitamin and mineral deficiencies \\
\hline
\end{tabular}

\section{Hypertesion diagnosis}

Ambulatory blood pressure monitoring (ABPM) is the most accurate technique to detect hypertension when a person has been examined and confirmed to have high blood pressure [99-101]. It is advised by guidelines to confirm increased blood pressure readings on a regular basis. Portable, automated cuffs are commonly used in ambulatory monitors, which measure blood pressure every 15-30 min during the day and every 15-60 min overnight [102]. Despite their diagnostic value, ambulatory monitors may be out of reach for many physicians and patients due to cost and time constraints and they can be inconvenient and disturb daily life and sleep $[103,104]$. However, technological advancements have enabled the creation of new 'cuffless BP monitoring devices that continually measure blood pressure without interfering with regular activities. Smartphone or wearable sensor technology can estimate blood pressure via ECG signals, photoplethysmogram (PPG) signals (using infrared light on the finger to determine skin blood flow), or a combination of both [105]. A wearable wristband to collect PPG data, a wearable heart rate belt to collect ECG signals, and a smartphone, for example, are all part of one system created. The signals from the wearable gadget communicate with the smartphone through Bluetooth to synchronise their measurements and transmit the wearer's blood pressure in real-time. Other devices have been created that calculate and record blood pressure measures using sensors in T-shirts [106], behind the ear [107], and in a computer mouse [108].

As with screening, the use of "smartphone apps" to assist in diagnosis is becoming more prevalent. According to a poll of 'app users' in the United States, 31\% of mobile phone owners used their phone to hunt for health information, with smartphone users accounting for the majority (52\%) [109]. Despite the fact that this is a rapidly growing industry, with over 180 blood pressure apps already available, only 3.8 percent $(7 / 184)$ of the blood pressure apps claimed any involvement of medical specialists in their development, and only a few apps have been rigorously tested [109]. Furthermore, the US Food and Drug Administration and the European Commission have yet to formally approve any mobile apps for use as measuring/diagnostic equipment. When one prominent mobile app was examined, the American Heart Association (AHA) found that there are too many inaccuracies with smart phone blood 
pressure apps [110], with mobile app-based blood pressure measures being wrong four out of five times $[109,110]$.

\section{Inflammation and hypertension}

Innate immune responses are quick and aren't exclusive to a single pathogen. They rely on phagocytic cells to recognise pathogenassociated molecular patterns (PAMPs) that are common to many pathogens but not found in the host or host-derived endogenous molecules that form as a result of cell death and injury [damageassociated molecule patterns (DAMPs) $[111,112]$. These pathogenassociated compounds trigger inflammatory responses as well as neutrophil and macrophage phagocytosis. Both cell types have a variety of pattern recognition receptors on their cell surfaces (PRR). Toll-like receptors (TLRs), nucleotide-binding oligomerization domain receptors (NOD-like receptors), leucine-rich repeat (LRR)containing proteins, retinoic acid-inducible gene (RIG)-like receptors (RLRs), and C-type lectin receptors (CLRs) recognise a variety of ligands, including lipopolysaccharide, peptidoglycans, [113-115]. The pro-inflammatory transcription factor nuclear-factor kappa-light-chain enhancer of activated B cells (NF-B) and the NACHT, LRR, and PYD domains-containing protein 3 (NLRP3) inflammasome are activated when TLRs are activated, resulting in the production of both signalling molecules such as prostaglandins and cytokines/chemokines. [115-117]. These cytokines attract neutrophils, monocytes, and dendritic cells, speeding up phagocytosis, acute-phase protein synthesis, and the adaptive immune system's transition to either the cell-mediated T-helper 1 (Th1) or humoral/antibody T-helper 2 (Th2) response. Although short-term inflammation is required for tissue defence, prolonged and excessive activation of the innate immune system causes harmful maladaptations and chronic inflammatory disorders like hypertension.

\section{Monocyte/macrophages}

Monocytes are specialised circulating cells with chemokine receptors and PRRs that allow for the rapid recognition and phagocytosis of endogenous bacteria and host-derived compounds, resulting in the production of pro-inflammatory cytokines and the recruitment of immune cells [118]. Macrophages are phagocytic resident cells that remove apoptotic cells and release growth factors, resulting in tissue homeostasis. Macrophages also have a variety of PRRs that help with phagocytosis and can convey antigens to T cells by releasing cytokines and increasing inflammation [113]. The production of hypertension by intravenous injection of splenic cells from hypertensive deoxycorticosterone acetate (DOCA) salt-treated animals into normotensive rats provided evidence for the crucial function of macrophages in hypertension. Mononuclear infiltrates in the arterial and arteriolar walls, along with exudative thickening of the intima, caused luminal narrowing, resistance to peripheral blood flow, and hypertension, according to biopsies of recipients' kidneys and hearts. This suggests that activated innate immune cells are sufficient to cause hypertension [119].

\section{Neutrophils}

Neutrophils are a type of myeloid cell that account for the majority of leukocytes in circulation. These innate immune cells are the initial line of defence against bacterial infection, but their significance in hypertension-related chronic inflammation is less clear [120]. Myeloperoxidase is one promising way by which neutrophils may mediate hypertension (MPO). Myeloperoxidase is a member of the heme peroxidase superfamily that is found mostly in neutrophils and monocytes. It produces reactive oxidants and radical species that are involved in lipid peroxidation. It's abundant in human atherosclerotic plaques, but it could also play a role in hypertension by acting as a nitric oxide catalytic sink [121]. In animal models, MPO-produced hypochlorous acid interacts with L-arginine to produce compounds that impair endothelial function by blocking NO production and acetylcholine-induced aortic relaxation [122]. Hypochlorous acid has also been shown to change high-density lipoprotein, causing endothelial nitric oxide synthase (NOS) to be displaced from its regular plasma membrane site, reducing its activity [123]. MPO and hypochlorous acid both lower the availability of NADPH, an important NOS cofactor [124]. These effects were shown in vivo in an MPO deletion mouse model, where mice were protected against toxemia-induced impairment of endothelial-dependent vascular relaxation [125], and in a pig model, where MPO injection resulted in reduced arterial blood flow [126]. These findings point to MPO's significance in hypertension regulation and its route as a potential therapeutic target in hypertension and cardiovascular disease.

\section{Dendritic cells}

Dendritic cells are cells that originate in the bone marrow and are found in the blood, lymphoid organs, and tissues. To activate $T$ lymphocytes and control inflammatory responses, these professional antigen-presenting cells efficiently function as a bridge between the innate and adaptive immune systems [127]. Dendritic cells are classified in a variety of ways, but the most common are plasmacytoid dendritic cells and two types of conventional dendritic cells, while dendritic cells can also come from the monocyte lineage. Several mouse models have demonstrated the importance of dendritic cells in the development of Ang II-responsive hypertension, including transgenic mice lacking CD11-positive dendritic cells and mice lacking the Fms-like tyrosine kinase 3 ligand, which allows conventional dendritic cells to develop [128, 129]. AT1R appears to have an effect on dendritic cell differentiation. Dendritic cells with AT1R deletion produce less inflammatory cytokine and are less activated in response to lipopolysaccharide, implying a key link between dendritic cells and the renin-angiotensin system [130].

Dendritic cells impact T-cell activation to influence blood pressure through a variety of methods. T-cell activation necessitates not just antigen presentation to the $\mathrm{T}$-cell receptor via a major histocompatibility complex, but also additional costimulatory interaction between the T cell and the dendritic cell. The interaction of B7 ligands (CD80 and CD86) on dendritic cells with CD27 on T cells is required for naive T-cell activation. Induced hypertension in mice by Ang II increases CD86 expression in dendritic cells. Blocking B7-dependent costimulation or deleting B7 ligands lowers Ang II-or DOCA salt-induced hypertension, and in fact, existing hypertension can be reversed with costimulation blocking [131]. Similarly, memory T-cell development requires costimulatory interaction between CD70 on dendritic cells and CD27 on T cells. In a mouse model of recurrent hypertensive stress, increased expression of dendritic cell CD70 leads to an accumulation of memory T cells in the kidney and bone marrow, which release interferon-gamma (IFN) and IL-17A, two cytokines linked to hypertension. Salt-sensitive hypertension develops in mice as a result of the buildup of bone marrow memory $\mathrm{T}$ cells and their extension to the kidney. The deletion of CD70 eliminates hypertension and memory T-cell responses [132]. Aldosterone activates dendritic cells in a similar way, resulting in an increase in IL-17-producing $\mathrm{T}$ cells that can be inhibited using mineralocorticoid receptor antagonists [133]. The ubiquitin-editing protein $\mathrm{A} 20$, on the other hand, appears to inhibit $\mathrm{T}$-cell activation in dendritic cells. In mice, heterozygous deletion of A20 in CD11c-positive dendritic cells causes an exacerbated hypertensive response to low-dose Ang II infusion as well as an increase in TNF and IFN-secreting memory T cells in the kidney [134]. These data imply that dendritic cells play a critical role in the T-cell activation that causes hypertension.

\section{T and B lymphocytes}

$\mathrm{T}$ and $\mathrm{B}$ cells are key players in adaptive immunity, influencing and being impacted by the innate immune system. Antigen-presenting cells in the innate immune system (dendritic cells, macrophages, innate-like B cells, and others) customise $\mathrm{T}$ cell development and adaptive responses to antigens [135]. Lymphocytes also share innate immunity properties such antigen and cytokine detection in both $B$ and $T$ cells, as well as the presence of several TLR on T lymphocytes [136]. Several studies demonstrating the function of adaptive immunity in the development of hypertension will be discussed in this section.

\section{T lymphocytes}

$\mathrm{T}$ cells mature in the thymus and then travel to lymphoid organs like the spleen and lymph nodes, where they remain inactive until they 
are activated by an antigen-presenting cell. $\mathrm{T}$ cells have been linked to hypertension through a variety of processes, including the generation and activation of cytokines, as well as infiltration of the renal vasculature and the central nervous system. The thymus is an important organ for T cell growth and education. Early research in athymic mice revealed that lymphocyte depletion results in the prevention or correction of hypertension in a variety of mouse models [137-140]. Salt-induced hypertension is resistant in athymic DOCA-treated mice, but thymus transplantation restores salt sensitivity [141]. The immunosuppressant cyclophosphamide reduces the hypertensive response of Sprague-Dawley rats after a partial renal infarction. The Lyon strain of genetically hypertensive rats showed similar results [141, 142]. Furthermore, transferring lymph node cells from rats with renal infarction or splenocytes from DOCA salt-treated rats to normal rats raises blood pressure in the recipient, implying that the development of hypertension requires an intact T-cell immune system $[119,143]$.

\section{B lymphocytes}

B lymphocytes, with their ability to recognise and process antigens as well as make antibodies, are essential for adaptive immunity. Several investigations have found that severely hypertensive people have high levels of IgG, IgM, and IgA antibodies [144, 145]. Ang II infusion increases the amount of splenic B cells and circulating IgGs in mice, as well as causing significant IgG buildup in the aortic adventitia. Furthermore, depletion/regulation of B-cell activity via immunological modulation (e. g., rituximab) or knockout models such as B-cell activating factor receptor knockout (BAFF-R/) mice has been demonstrated to reduce mean arterial pressure and the hypertensive response to Ang II in several investigations [146, 147]. In a mouse model of SLE mice, alternative medicines such as bortezomib, a proteasome inhibitor that reduces plasma cell antibody production, have showed promise in reducing bone marrow plasma cells. Bortezomib treatment reduced renal injury/glomerulosclerosis, B and T lymphocyte infiltration into the kidney, and mean arterial pressure in mice [147]. These findings are in contrast to recent research that suggests that adoptive transfer of $\mathrm{T}$ cells but not $\mathrm{B}$ cells restores Ang II-induced hypertension in RAG$1 /$ mice [146]. This apparent contradiction, however, could indicate that B-cell activation necessitates contact with $\mathrm{T}$ cells, and the two types of cells may have separate methods for causing hypertension.

\section{CONCLUSION}

Hypertension has been identified as a significant risk factor for the development of a variety of cardiovascular illnesses. There is clear evidence that lifestyle factors may alter blood pressure values based on current literature data. Then, in hypertension individuals, lifestyle adjustments can have a beneficial effect, lowering global cardiovascular risk and all-cause death.

The role of immunity as a common thread underpinning multiple organ systems' hypertension processes. Exploring the genetic and environmental variables that predispose these cells to react to common stimuli, as well as gaining a better knowledge of how immune cells communicate with target organs to induce hypertension, can help us create new treatments for this prevalent disease.

\section{FUNDING}

Nil

\section{AUTHORS CONTRIBUTIONS}

All the authors have contributed equally.

\section{CONFLICTS OF INTERESTS}

Declared none

\section{REFERENCES}

1. World Health Organization. A global brief on hypertension; April 2013. Contract No.: WHO/DCO/WHD/2013.

2. Carretero OA, Oparil S. Essential hypertension. part I: Definition and etiology. Circulation. 2000;101(3):329-35. doi: 10.1161/01.cir.101.3.329. PMID 10645931.
3. Oparil S, Zaman MA, Calhoun DA. Pathogenesis of hypertension. Ann Intern Med. 2003;139(9):761-76. doi: 10.7326/00034819-139-9-200311040-00011, PMID 14597461.

4. Hall JE, Guyton AC. Textbook of medical physiology. St. Louis: Elsevier Saunders. ISBN 0-7216-0240-1; 2006. p. 228.

5. Nandhini S. Hypertension: eMedicine nephrology; 2009.

6. Bhor RJ, Kotade KB, Wagh VD. Essential hypertension: the Lancet; 2009.

7. Anderson KM, Odell PM, Wilson PWF, Kannel WB. Cardiovascular disease risk profiles. Am Heart J. 1991;121(1 Pt 2):293-8. doi: 10.1016/0002-8703(91)90861-b, PMID 1985385.

8. Weber MA, Schiffrin EL, White WB, Mann S, Lindholm LH, Kenerson JG, Flack JM, Carter BL, Materson BJ, Ram CV, Cohen DL, Cadet JC, Jean-Charles RR, Taler S, Kountz D, Townsend RR, Chalmers J, Ramirez AJ, Bakris GL, Wang J, Schutte AE, Bisognano JD, Touyz RM, Sica D, Harrap SB. Clinical practice guidelines for the management of hypertension in the community: a statement by the American Society of Hypertension and the international society of hypertension. J Clin Hypertens (Greenwich). 2014;16(1):14-26. doi: 10.1111/jch.12237, PMID 24341872.

9. Weber MA, Schiffrin EL, White WB, Mann S, Lindholm LH, Kenerson JG, Flack JM, Carter BL, Materson BJ, Ram CV, Cohen DL, Cadet JC, Jean-Charles RR, Taler S, Kountz D, Townsend RR, Chalmers J, Ramirez AJ, Bakris GL, Wang J, Schutte AE, Bisognano JD, Touyz RM, Sica D, Harrap SB. Clinical practice guidelines for the management of hypertension in the community A statement by the American Society of Hypertension and the International Society of Hypertension. J Hypertens. 2014;32(1):3-15. doi: 10.1097/ HJH.0000000000000065, PMID 24270181.

10. Carretero OA, Oparil S. Essential hypertension: part II: Treatment. See comment in PubMed Commons below Circulation. 2000;101(4):446-53. doi: 10.1161/ 01.cir.101.4.446, PMID 10653838.

11. Beevers G, Lip GY, O'Brien E. ABC of hypertension: the pathophysiology of hypertension. BMJ. 2001;322(7291):912-6. doi: 10.1136/bmj.322.7291.912, PMID 11302910.

12. Bartosh SM, Aronson AJ. Childhood hypertension. An update on etiology, diagnosis, and treatment. Pediatr Clin North Am. 1999;46(2):235-52. doi: 10.1016/s0031-3955(05)70115-2, PMID 10218072.

13. Osmond C, Barker DJ. Fetal, infant, and childhood growth are predictors of coronary heart disease, diabetes, and hypertension in adult men and women. Environ Health Perspect. 2000;108;Suppl 3:545-53. doi: 10.1289/ ehp.00108s3545, PMID 10852853.

14. The Fourth Report on the Diagnosis, Evaluation, and Treatment of High Blood Pressure in Children and Adolescents. Pediatrics. 2004;114(2):555-76. doi: 10.1542/peds.114.2.S2.555.

15. Contreras F, Rivera M, Vasquez J, De la Parte MA, Velasco M. Diabetes and hypertension physiopathology and therapeutics. J Hum Hypertens. 2000;14;Suppl 1:S26-31. doi: 10.1038/ sj.jhh.1000983, PMID 10854077.

16. Federation of Associated Societies for Experimental Biology. Third report on nutrition monitoring in the United States. Vol. 1. Washington, DC: US Government Printing Office; 1995.

17. Joseph L, Fauci AS, Eugene B, Kasper DL, Hauser Stephen L, Longo Dan L. Harrison's principles of internal medicine. McGraw-Hill Medical; 2008.

18. Dustan HR, Tarazi RC, Bravo EL. Diuretic and diet treatment of hypertension. Arch Intern Med. 1974;133(6):1007-13, PMID 4829750.

19. Haffner SM, Lehto S, Ronnemaa T, Pyorala K, Laakso M. Mortality from coronary heart disease in subjects with type 2 diabetes and in nondiabetic subjects with and without prior myocardial infarction. N Engl J Med. 1998;339(4):229-34. doi: 10.1056/NEJM199807233390404, PMID 9673301.

20. Lindhorst J, Alexander N, Blignaut J, Rayner B. Differences in hypertension between blacks and whites: an overview. Cardiovasc J Afr. 2007;18(4):241-7. PMID 17940670.

21. Burt VL, Whelton P, Roccella EJ, Brown C, Cutler JA, Higgins M, Horan MJ, Labarthe D. Prevalence of hypertension in the US adult population. Results from the third National Health and 
nutrition Examination Survey, 1988-1991. Hypertension. 1995;25(3):305-13. doi: 10.1161/01.hyp.25.3.305. PMID 7875754.

22. Haslam DW, James WPT. Obesity. Lancet. 2005;366(9492):1197209. doi: 10.1016/S0140-6736(05)67483-1.

23. Katori M, Majima M. A missing link between a high salt intake and blood pressure increase, Japan February; 2006.

24. Jurgens G, Graudal NA. Effects of low sodium diet versus high sodium diet on blood pressure, renin, aldosterone, catecholamines, cholesterols, and triglyceride. In Graudal, Niel Albert. Cochrane Database Syst Rev. 2004;1:pub2: CD004022:CD004022. doi: 10.1002/14651858.

25. Aburto NJ, Ziolkovska A, Hooper L, Elliott P, Cappuccio FP, Meerpohl JJ. Effect of lower sodium intake on health: systematic review and meta-analyses. BMJ. 2013;346:f1326. doi: 10.1136/bmj.f1326. PMID 23558163.

26. He FJ, Li J, Macgregor GA. Effect of longer term modest salt reduction on blood pressure: cochrane systematic review and meta-analysis of randomised trials. BMJ. 2013;346:f1325. doi: 10.1136/bmj.f1325. PMID 23558162.

27. Neter JE, Stam BE, Kok FJ, Grobbee DE, Geleijnse JM. Influence of weight reduction on blood pressure: a meta-analysis of randomized controlled trials. Hypertension. 2003;42:878-84. doi: 10.1161/01. HYP.0000094221.86888. AE.

28. Cornelissen VA, Smart NA. Exercise training for blood pressure: A systematic review and meta-analysis. J Am Heart Assoc. 2013;2(1):e004473. doi: 10.1161/JAHA.112.004473, PMID 23525435.

29. Carlson DJ, Dieberg G, Hess NC, Millar PJ, Smart NA. Isometric exercise training for blood pressure management: A systematic review and meta-analysis. Mayo Clin Proc. 2014;89(3):327-34. doi: 10.1016/j.mayocp.2013.10.030, PMID 24582191. mayocp.2013.10.030.

30. Whelton PK, HE J, Cutler JA, Brancati FL, Appel LJ, Follmann D, Klag MJ. Effects of oral potassium on blood pressure. Metaanalysis of randomized controlled clinical trials. JAMA. 1997;277(20):1624-32. 10.1001/jama.1997.03540440058033, PMID 9168293.

31. 31. Whelton PK, Carey RM, Aronow WS, Casey DE, Collins KJ, Himmelfarb CD, DePalma SM, Gidding S, Jamerson KA, Jones DW, MacLaughlin KJ, Muntner P, Ovbiagele B, Smith SC, Spencer CC, Stafford RS, Taler SJ, Thomas RJ, Williams KA, Williamson JD, Wright JT. Guideline for the prevention, detection, evaluation, and management of high blood pressure in adults: A report of the American College of Cardiology/American Heart Association Task Force on Clinical Practice guidelines. J Am Coll Cardiol. 2018;71:e127-248. doi: 10.1016/j. jacc.2017.11.006.

32. Goit N, Yang SN. The antihypertensive and lipid-lowering treatment to prevent heart attack trial (ALLHAT). Major outcomes in high-risk hypertensive patients Rando-L. JAMA. 2002;288:119. doi: 10.1001/jama.288.23.2981.

33. Law MR, Morris JK, Wald NJ. Use of blood pressure lowering drugs in the prevention of cardiovascular disease: metaanalysis of 147 randomised trials in the context of expectations from prospective epidemiological studies. BMJ. 2009;338:b1665. doi: 10.1136/bmj.b1665. PMID 19454737.

34. Aronow WS, Fleg JL, Pepine CJ, Artinian NT, Bakris G, Brown AS, Ferdinand KC, Forciea MA, Frishman WH, Jaigobin C, Kostis JB, Mancia G, Oparil S, Ortiz E, Reisin E, Rich MW, Schocken DD, Weber MA, Wesley DJ, Harrington RA, ACCF Task Force. ACCF/AHA 2011 expert consensus document on hypertension in the elderly: A report of the American college of cardiology foundation task force on clinical expert consensus documents. Circulation. 2011;123(21):2434-506. doi: 10.1161/ CIR.0b013e31821daaf6, PMID 21518977.

35. Emdin CA, Rahimi K, Neal B, Callender T, Perkovic V, Patel A Blood pressure lowering in Type 2 diabetes: A systematic review and meta-analysis. JAMA. 2015;313(6):603-15. doi: 10.1001/jama.2014.18574, PMID 25668264.

36. Turnbull F, Neal B, Algert C, Chalmers J, Chapman N, Cutler J, Woodward M, MacMahon S, Blood Pressure Lowering Treatment Trialists' Collaboration. Effects of different blood pressure-lowering regimens on major cardiovascular events in individuals with and without diabetes mellitus: results of prospectively designed overviews of randomized trials. Archives of Internal Medicine. 2005;165(12):1410-9. https://doi.org/10.1001/archinte.165.12.1410doi: 10.1001/archinte.165.12.1410, PMID 15983291

37. Palmer SC, Mavridis D, Navarese E, Craig JC, Tonelli M, Salanti G, Wiebe N, Ruospo M, Wheeler DC, Strippoli GFM. Comparative efficacy and safety of blood pressure-lowering agents in adults with diabetes and kidney disease: A network meta-analysis. Lancet. 2015;385(9982):2047-56. https://doi.org/10.1016/ S0140-6736(14)62459-4

38. Schmieder RE, Hilgers KF, Schlaich MP, Schmidt BMW. Reninangiotensin system and cardiovascular risk. Lancet. 2007;369(9568):1208-19. doi: 10.1016/S0140 6736(07)60242-6.

39. Pucci M, Sarween N, Knox E, Lipkin G, Martin U. Angiotensinconverting Enzyme Inhibitors and angiotensin receptor blockers in women of childbearing age: risks versus Benefits. Expert Review of Clinical Pharmacology. 2015;8(2):221-31. https://doi.org/10.1586/17512433.2015.1005074

40. Ferrer RL, Sibai BM, Mulrow CD, Chiquette E, Stevens KR, Cornell J. Management of mild chronic hypertension during pregnancy: a review. Obstetrics and Gynecology. 2000;96(5 Pt 2):849-60. doi: 10.1016/s0029-7844(00)00938-8, PMID 11094241.

41. Moretti ME, Caprara D, Drehuta I, Yeung E, Cheung S, Federico L, Koren G. The fetal safety of angiotensin converting enzyme inhibitors and angiotensin II receptor blockers. Obstetrics and Gynecology International. 2012. https://doi.org/ $10.1155 / 2012 / 658310$

42. James PR, Nelson-Piercy C. Management of hypertension before, during, and after pregnancy. Heart. 2004;90(12):1499504. https://doi.org/10.1136/hrt.2004.035444doi: 10.1136/ hrt.2004.035444, PMID 15547046.

43. Graudal NA, Galløe AM, Garred P. Effects of sodium restriction on blood pressure, renin, aldosterone, catecholamines, cholesterols, and triglyceride: A meta-analysis. JAMA. 1998;279(17):1383-91. doi: 10.1001/jama.279.17.1383, PMID 9582047.

44. Yuan BX, Leenen FH. Dietary sodium intake and left ventricular hypertrophy in normotensive rats. Am J Physiol. 1991;261(5 Pt 2):1397-1401H1397-401.

10.1152/ajpheart.1991.261.5.H1397, PMID 1835307.

45. Kim S, Ohta K, Hamaguchi A, Yukimura T, Miura K, LIwao H. Angiotensin II induces cardiac phenotypic modulation and remodeling in vivo in rats. Hypertension. 1995;25(6):1252-9. doi: 10.1161/01.hyp.25.6.1252, PMID 7768570.

46. Matavelli LC, Zhou X, Varagic J, Susic D, Frohlich ED. Salt-loading produces severe renal hemodynamic dysfunction independent of arterial pressure in spontaneously hypertensive rats. Am J Physiol Heart Circ Physiol. 2007;292(2):814-819H814-9. doi: 10.1152/ajpheart.00671.2006, PMID 16997890.

47. Anh J, Varagic J, Slama M, Susic D, Frohlich ED. Cardiac structural and functional responses to salt loading in SHR. Am J Physiol Heart Circ Physiol. 2004;284:767-72.

48. Morgan T. Renin, angiotensin, sodium and organ damage. Hypertens Res. 2003;26(5):349-54. doi 10.1291/hypres.26.349, PMID 12887125.

49. Dickinson KM, Clifton PM, Keogh JB. A reduction of $3 \mathrm{~g} /$ day from a usual $9 \mathrm{~g} /$ day salt diet improves endothelial function and decreases endothelin- 1 in a randomised cross_over study in normotensive overweight and obese subjects. Atherosclerosis. 2014;233(1):32-8. doi: 10.1016/ j.atherosclerosis.2013.11.078, PMID 24529119.

50. Gijsbers L, Dower JI, Schalkwijk CG, Kusters YH, Bakker SJ, Hollman PC, Geleijnse JM. Effects of sodium and potassium supplementation on endothelial function: A fully controlled dietary intervention study. Br J Nutr. 2015;114(9):1419-26. doi: 10.1017/S0007114515002986, PMID 26343780.

51. Jablonski KL, Racine ML, Geolfos CJ, Gates PE, Chonchol M, McQueen MB, Seals DR. Dietary sodium restriction reverses vascular endothelial dysfunction in middle-aged/older adults with moderately elevated systolic blood pressure. J Am Coll Cardiol. 2013;61(3):335-43. doi: 10.1016/j.jacc.2012.09.010, PMID 23141486. 
52. Dickinson KM, Keogh JB, Clifton PM. Effects of a low-salt diet on flow-mediated dilatation in humans. Am J Clin Nutr. 2009;89(2):485-90. doi: 10.3945/ajcn.2008.26856, PMID 19106240.

53. Strazzullo P, D’Elia L, Kandala NB, Cappuccio FP. Salt intake, stroke, and cardiovascular disease: meta-analysis of prospective studies. BMJ. 2009;339:b4567. doi: 10.1136/bmj.b4567, PMID 19934192.

54. Ezzati M, Henley SJ, Thun MJ, Lopez AD. Role of smoking in global and regional cardiovascular mortality. Circulation. 2005;112(4):489-97. doi: 10.1161/circulationaha.104.521708, PMID 16027251.

55. Neunteufl T, Heher S, Kostner K, Mitulovic G, Lehr S, Khoschsorur G, Schmid RW, Maurer G, Stefenelli T. Contribution of nicotine to acute endothelial dysfunction in long-term smokers. J Am Coll Cardiol. 2002;39(2):251-6. doi: 10.1016/s0735-1097(01)01732-6, PMID 11788216.

56. Celermajer DS, Adams MR, Clarkson P, Robinson J, McCredie R, Donald A, Deanfield JE. Passive smoking and impaired endothelium-dependent arterial dilatation in healthy young adults. N Engl J Med. 1996;334(3):150-4. doi: 10.1056/NEJM199601183340303, PMID 8531969.

57. Strong JP, Richards ML. Cigarette smoking and atherosclerosis in autopsied men. Atherosclerosis. 1976;23(3):451-76. doi: 10.1016/0021-9150(76)90007-1, PMID 1267863.

58. Castardeli E, Duarte DR, Minicucci MF, Azevedo PS, Matsubara BB, Matsubara LS, Campana AO, Paiva SA, Zornoff LA. Exposure time and ventricular remodeling induced by tobacco smoke exposure in rats. Med Sci Monit. 2008;14(3):BR62-66. PMID 18301351.

59. Strachan DP. Predictors of death from aortic aneurysm among middle-aged men: the Whitehall study. Br J Surg. 1991;78(4):4014. doi: 10.1002/bjs.1800780407, PMID 2032097.

60. Hughes K, Leong WP, Sothy SP, Lun KC, Yeo PP. Relationships between cigarette smoking, blood pressure and serum lipids in the Singapore general population. Int J Epidemiol. 1993;22(4):637-43. doi: 10.1093/ije/22.4.637, PMID 8225737.

61. Mahmud A, Feely J. Effects of passive smoking on blood pressure and aortic pressure waveform in healthy young adults--influence of gender. $\mathrm{Br} \mathrm{J}$ Clin Pharmacol. 2004;57(1):37-43. doi: 10.1046/j.1365-2125.2003.01958.x, PMID 14678338.

62. Yarlioglues M, Kaya MG, Ardic I, Calapkorur B, Dogdu O, Akpek M, Ozdogru M, Kalay N, Dogan A, Ozdogru I, Oguzhan A. Acute effects of passive smoking on blood pressure and heart rate in healthy females. Blood Press Monit. 2010;15(5):251-6. doi: 10.1097/MBP.0b013e32833e439f, PMID 20729727.

63. Bowman TS, Gaziano JM, Buring JE, Sesso HD. A prospective study of cigarette smoking and risk of incident hypertension in women. J Am Coll Cardiol. 2007;50(21):2085-92. doi: 10.1016/j.jacc.2007.08.017, PMID 18021879.

64. Polosa R, Morjaria JB, Caponnetto P, Battaglia E, Russo C, Ciampi C, Adams G, Bruno CM. Blood pressure control in smokers with arterial hypertension who switched to electronic cigarettes. Int J Environ Res Public Health. 2016;13(11). doi: 10.3390/ijerph13111123, PMID 27845734.

65. Abe H, Kawano Y, Kojima S, Ashida T, Kuramochi M, Matsuoka H, Omae T. Biphasic effects of repeated alcohol intake on 24-hour blood pressure in hypertensive patients. Circulation. 1994;89(6):2626-33. doi: 10.1161/01.cir.89.6.2626, PMID 8205674.

66. Klatsky AL. Alcohol and cardiovascular disease--more than one paradox to consider. Alcohol and hypertension: does it matter? Yes J Cardiovasc Risk. 2003;10(1):21-4. doi: 10.1097/ 01.hjr.0000051960.68260.79, PMID 12569233.

67. Puddey IB, Beilin LJ, Rakic V. Alcohol, hypertension and the cardiovascular system: A critical appraisal. Addict Biol. 1997;2(2):159-70. doi: 10.1080/13556219772705, PMID 26735633.

68. Puddey IB, Beilin LJ. Alcohol is bad for blood pressure. Clin Exp Pharmacol Physiol. 2006;33(9):847-52. doi: 10.1111/j.14401681.2006.04452.x, PMID 16922819.

69. Okubo Y, Suwazono Y, Kobayashi E, Nogawa K. Alcohol consumption and blood pressure change: 5-year follow-up study of the association in normotensive workers. J Hum Hypertens. 2001;15(6):367-72. doi: 10.1038/sj.jhh.1001191, PMID 11439310.
70. Fuchs FD, Chambless LE, Whelton PK, Nieto FJ, Heiss G. Alcohol consumption and the incidence of hypertension: the Atherosclerosis Risk in Communities Study. Hypertension. 2001;37(5):1242-50. doi: 10.1161/01.hyp.37.5.1242, PMID 11358935.

71. Bell RA, Mayer Davis EJ, Martin MA, D'Agostino RB Jr, Haffner SM. Associations between alcohol consumption and insulin sensitivity and cardiovascular disease risk factors: the insulin Resistance and Atherosclerosis Study. Diabetes Care. 2000;23(11):1630-6. doi: 10.2337/diacare.23.11.1630, PMID 11092284.

72. Koppes LL, Dekker JM, Hendriks HF, Bouter LM, Heine RJ. Moderate alcohol consumption lowers the risk of type 2 diabetes: A meta-analysis of prospective observational studies. Diabetes Care. 2005;28(3):719-25. doi: 10.2337/diacare.28.3.719, PMID 15735217.

73. Beulens JW, Rimm EB, Hendriks HF, Hu FB, Manson JE, Hunter DJ, Mukamal KJ. Alcohol consumption and type 2 diabetes: influence of genetic variation in alcohol dehydrogenase. Diabetes. 2007;56(9):2388-94. doi: 10.2337/db07-0181, PMID 17563066.

74. Thijssen DH, Dawson EA, van den Munckhof IC, Birk GK, Timothy Cable NT, Green DJ. Local and systemic effects of leg cycling training on arterial wall thickness in healthy humans. Atherosclerosis. 2013;229(2):282-6. doi: 10.1016/j.atherosclerosis.2013.05.013, PMID 23880177.

75. Hoier B, Hellsten Y. Exercise-induced capillary growth in human skeletal muscle and the dynamics of VEGF. Microcirculation. 2014;21(4):301-14. doi: 10.1111/micc.12117, PMID 24450403.

76. Gliemann L, Buess R, Nyberg M, Hoppeler H, Odriozola A, Thaning P, Hellsten Y, Baum O, Mortensen SP. Capillary growth, ultrastructure remodelling and exercise training in skeletal muscle of essential hypertensive patients. Acta Physiol (Oxf). 2015;214(2):210-20. doi: 10.1111/apha.12501, PMID 25846822.

77. Blair SN, Goodyear NN, Gibbons LW, Cooper KH. Physical fitness and incidence of hypertension in healthy normotensive men and women. JAMA. 1984;252(4):487-90, PMID 6737638.

78. Haapanen N, Miilunpalo S, Vuori I, Oja P, Pasanen M. Association of leisure time physical activity with the risk of coronary heart disease, hypertension and diabetes in middleaged men and women. Int J Epidemiol. 1997;26(4):739-47. doi: 10.1093/ije/26.4.739, PMID 9279605.

79. Paffenbarger Jr RS, Wing AL, Hyde RT, Jung DL. Physical activity and incidence of hypertension in college alumni. Am J Epidemiol. 1983;117(3):245-57. 10.1093/oxfordjournals.aje.a113537, PMID 6829553.

80. Leitzmann MF, Park Y, Blair A, Ballard-Barbash R, Mouw T, Hollenbeck AR, Schatzkin A. Physical activity recommendations and decreased risk of mortality. Arch Intern Med. 2007;167(22):2453-60. doi: 10.1001/archinte.167.22.2453, PMID 18071167.

81. Rossi A, Dikareva A, Bacon SL, Daskalopoulou SS. The impact of physical activity on mortality in patients with high blood pressure: A systematic review. J Hypertens. 2012;30(7):127788. doi: 10.1097/HJH.0b013e3283544669, PMID 22573122.

82. James PA, Oparil S, Carter BL, Cushman WC, DennisonHimmelfarb C, Handler J, Lackland DT, LeFevre ML, MacKenzie TD, Ogedegbe O, Smith SC, Svetkey LP, Taler SJ, Townsend RR, Wright JT, Narva AS, Ortiz E. Evidence-based guideline for the management of high blood pressure in adults: report from the panel members appointed to the Eighth Joint National Committee (JNC 8). JAMA. 2014;311(5):507-20. doi: 10.1001/jama.2013.284427, PMID 24352797.

83. Mancia G, Fagard R, Narkiewicz K, Redón J, Zanchetti A, Bohm M, Christiaens T, Cifkova R, De Backer G, Dominiczak A, Galderisi M, Grobbee DE, Jaarsma T, Kirchhof P, Kjeldsen SE, Laurent S, Manolis AJ, Nilsson PM, Ruilope LM, Schmieder RE, Sirnes PA, Sleight P, Viigimaa M, Waeber B, Zannad F, Task Force Members. ESH/ESC Guidelines for the management of arterial hypertension: the Task Force for the management of arterial hypertension of the European Society of Hypertension (ESH) and of the European Society of Cardiology (ESC). J 
Hypertens. 2013;31(7):1281-357. doi: 10.1097/ 01.hjh.0000431740.32696.cc, PMID 23817082.

84. Stevens VJ, Corrigan SA, Obarzanek E, Bernauer E, Cook NR, Hebert P, Mattfeldt-Beman M, Oberman A, Sugars C, Dalcin AT. Weight loss intervention in phase 1 of the trials of hypertension prevention. The TOHP Collaborative Research Group. Arch Intern Med. 1993;153(7):849-58. doi: 10.1001/archinte.153.7.849, PMID 8466377.

85. Stevens VJ, Obarzanek E, Cook NR, Lee IM, Appel LJ, Smith West D, Milas NC, Mattfeldt-Beman M, Belden L, Bragg C, Millstone M, Raczynski J, Brewer A, Singh B, Cohen J. Trials for the hypertension prevention research group. Long-term weight loss and changes in blood pressure: results of the trials of hypertension prevention, phase II. Ann Intern Med. 2001;134(1):1-11. doi: 10.7326/0003-4819-134-1200101020-00007, PMID 11187414.

86. Huang Z, Willett WC, Manson JE, Rosner B, Stampfer MJ, Speizer FE, Colditz GA. Body weight, weight change, and risk for hypertension in women. Ann Intern Med. 1998;128(2):81-8. doi: 10.7326/00034819-128-2-199801150-00001, PMID 9441586.

87. Effects of weight loss and sodium reduction intervention on blood pressure and hypertension incidence in overweight people with high-normal blood pressure. The trials of hypertension prevention, phase II. The Trials of hypertension Prevention Collaborative Research Group. Arch Intern Med. 1997;157(6):657-67. doi: 10.1001/archinte.157.6.657, PMID 9080920 .

88. Langford HG, Blaufox MD, Oberman A, Hawkins CM, Curb JD, Cutter GR, Wassertheil-Smoller S, Pressel S, Babcock C, Abernethy JD. Dietary therapy slows the return of hypertension after stopping prolonged medication. JAMA. 1985;253(5):65764, PMID 3881608.

89. Whelton PK, Appel LJ, Espeland MA, Applegate WB, Ettinger WH Jr, Kostis JB, Kumanyika S, Lacy CR, Johnson KC, Folmar S, Cutler JA. Sodium reduction and weight loss in the treatment of hypertension in older persons: A randomized controlled trial of nonpharmacologic interventions in the elderly (TONE). TONE Collaborative Research Group. JAMA. 1998;279(11):839-46. doi: 10.1001/jama.279.11.839, PMID 9515998.

90. Cappuccio FP, MacGregor GA. Does potassium supplementation lower blood pressure? A meta-analysis of published trials. J Hypertens. 1991;9(5):465-73. doi: 10.1097/00004872199105000-00011, PMID 1649867.

91. Geleijnse JM, Kok FJ, Grobbee DE. Blood pressure response to changes in sodium and potassium intake: a metaregression analysis of randomised trials. J Hum Hypertens. 2003;17(7):47180. doi: 10.1038/sj.jhh.1001575, PMID 12821954.

92. Lavie CJ, Milani RV, Mehra MR, Ventura HO. Omega-3 polyunsaturated fatty acids and cardiovascular diseases. J Am Coll Cardiol. 2009;54(7):585-94. doi: 10.1016/j.jacc.2009.02.084, PMID 19660687.

93. Tousoulis D, Plastiras A, Siasos G, Oikonomou E, Verveniotis A, Kokkou E, Maniatis K, Gouliopoulos N, Miliou A, Paraskevopoulos T, Stefanadis C. Omega-3 PUFAs improved endothelial function and arterial stiffness with a parallel antiinflammatory effect in adults with metabolic syndrome. Atherosclerosis. 2014;232(1):10-6. 10.1016/j.atherosclerosis.2013.10.014, PMID 24401211.

94. Bønaa KH, Bjerve KS, Straume B, Gram IT, Thelle D. Effect of eicosapentaenoic and docosahexaenoic acids on blood pressure in hypertension. A population-based intervention trial from the Troms $\emptyset$ study. N Engl J Med. 1990;322(12):795-801. doi: 10.1056/NEJM199003223221202, PMID 2137901.

95. Prisco D, Paniccia R, Bandinelli B, Filippini M, Francalanci I, Giusti B, Giurlani L, Gensini GF, Abbate R, Neri Serneri GG. Effect of medium-term supplementation with a moderate dose of $n-3$ polyunsaturated fatty acids on blood pressure in mild hypertensive patients. Thromb Res. 1998;91(3):105-112. doi: 10.1016/s0049-3848(98)00046-2, PMID 9733153.

96. Miller PE, Van Elswyk M, Alexander DD. Long-chain Oomega-3 fatty acids eicosapentaenoic acid and docosahexaenoic acid and blood pressure: A meta-analysis of randomized controlled trials. Am J Hypertens. 2014;27(7):885-96. doi: 10.1093/ajh/hpu024, PMID 24610882.
97. Yang B, Shi MQ, Li ZH, Yang JJ, Li D. Fish, long-chain n-3 PUFA and incidence of elevated blood pressure: A meta-analysis of prospective cohort studies. Nutrients. 2016;8(1). doi: 10.3390/nu8010058, PMID 26805877.

98. Fuhrman B, Aviram M. Flavonoids protect LDL from oxidation and attenuate atherosclerosis. Curr Opin Lipidol. 2001;12(1):41-8. doi: 10.1097/00041433-200102000-00008, PMID 11176202.

99. Excellence NIFC. NICE CG 107 hypertension-in-pregnancydiagnosis-and-management-pdf-35109334011877.pdf; 2011.

100. Mancia G, Fagard R, Narkiewicz K, Redon J, Zanchetti A, Böhm M, Christiaens T, Cifkova R, De Backer G, Dominiczak A, Galderisi M, Grobbee DE, Jaarsma T, Kirchhof P, Kjeldsen SE, Laurent S, Manolis AJ, Nilsson PM, Ruilope LM, Schmieder RE, Sirnes PA, Sleight P, Viigimaa M, Waeber B, Zannad F, Redon J, Dominiczak A, Narkiewicz K, Nilsson PM, Burnier M, Viigimaa M, Ambrosioni E, Caufield M, Coca A, Olsen MH, Schmieder RE, Tsioufis C, van de Borne P, Zamorano JL, Achenbach S, Baumgartner H, Bax JJ, Bueno H, Dean V, Deaton C, Erol C, Fagard R, Ferrari R, Hasdai D, Hoes AW, Kirchhof P, Knuuti J, Kolh P, Lancellotti P, Linhart A, Nihoyannopoulos P, Piepoli MF, Ponikowski P, Sirnes PA, Tamargo JL, Tendera M, Torbicki A, Wijns W, Windecker S, Clement DL, Coca A, Gillebert TC, Rosei EA, Ambrosioni E, Anker SD, Bauersachs J, Hitij JB, Caulfield M, De Buyzere M, De Geest S, Derumeaux GA, Erdine S, Farsang C, Funck-Brentano C, Gerc V, Germano G, Gielen S, Haller H, Hoes AW, Jordan J, Kahan T, Komajda M, Lovic D, Mahrholdt H, Olsen MH, Ostergren J, Parati G, Perk J, Polonia J, Popescu BA, Reiner Z, Ryden L, Sirenko Y, Stanton A, Struijker-Boudier H, Tsioufis C, van de Borne P, Vlachopoulos C, Volpe M, Wood DA. ESH/ESC guidelines for the management of arterial hypertension: the Task Force for the Management of Arterial Hypertension of the European Society of Hypertension (ESH) and of the European Society of Cardiology (ESC). Eur Heart J. 2013;34(28):2159219. doi: 10.1093/eurheartj/eht151. PMID 23771844.

101. Whelton PK, Carey RM, Aronow WS, Casey DE, Jr, Collins KJ, Dennison Himmelfarb C, DePalma SM, Gidding S, Jamerson KA, Jones DW, MacLaughlin EJ, Muntner P, Ovbiagele B, Smith SC, Spencer CC, Stafford RS, Taler SJ, Thomas RJ, Sr, Williams KA, Williamson JD, Jr, Wright JT. ACC/AHA/AAPA/ABC/ACPM/AGS/APhA/ASH/ASPC/NMA/PC NA guideline for the prevention, detection, evaluation, and management of high blood pressure in adults: executive summary: a report of the American College of Cardiology/American Heart Association Task Force on Clinical Practice Guidelines. Circulation. 2017;138(17):e426-e83.

102. Hinderliter AL, Voora RA, Viera AJ. Implementing ABPM into clinical practice. Curr Hypertens Rep. 2018;20(1):5. doi: 10.1007/s11906-018-0805-y, PMID 29404785.

103. Wood S, Greenfield SM, Sayeed Haque M, Martin U, Gill PS, Mant J, Mohammed MA, Heer G, Johal A, Kaur R, Schwartz C, McManus RJ. Influence of ethnicity on acceptability of method of blood pressure monitoring: a cross-sectional study in primary care. Br J Gen Pract. 2016;66(649):e577-86. doi: 10.3399/bjgp16X685717, PMID 27266860.

104. Little P, Barnett J, Barnsley L, Marjoram J, Fitzgerald-Barron A, Mant D. Comparison of acceptability of and preferences for different methods of measuring blood pressure in primary $\begin{array}{lll}\text { care. } & \text { BMJ. 2002;325(7358):258-9. doi: }\end{array}$ 10.1136/bmj.325.7358.258, PMID 12153924.

105. Stojanova A, Koceski S, Koceska N. Continuous blood pressure monitoring as a basis for ambient assisted living (AAL) - review of methodologies and devices. J Med Syst. 2019;43(2):24. doi: 10.1007/s10916-018-1138-8, PMID 30603777.

106. Nemati S, Lehman LW, Adams RP, Malhotra A. Discovering shared cardiovascular dynamics within a patient cohort. Annu Int Conf IEEE Eng Med Biol Soc. Proceedings of the annual international conference of the IEEE Engineering in Medicine and Biology Society IEEE Engineering in Medicine and Biology Society Annual Conference. Conference. 2012;2012:6526-9. doi: 10.1109/EMBC.2012.6347489, PMID 23367424.

107. Zhang Q, Zhou D, Zeng X. Highly wearable cuff-less blood pressure and heart rate monitoring with single-arm electrocardiogram and photoplethysmogram signals. Biomed 
Eng OnLine. 2017;16(1):23. doi: 10.1186/s12938-017-0317-z, PMID 28166774.

108. Kim J, Park J, Kim K, Chee Y, Lim Y, Park K. Development of a nonintrusive blood pressure estimation system for computer users. Telemed J E Health. 2007;13(1):57-64. doi: 10.1089/tmj.2006.0034, PMID 17309356.

109. Jamaladin H, van de Belt TH, Luijpers LC, de Graaff FR, Bredie SJ, Roeleveld N, van Gelder MM. Mobile apps for blood pressure monitoring: systematic search in app stores and content analysis. JMIR mHealth uHealth. 2018;6(11):e187. doi: 10.2196/mhealth.9888, PMID 30429116.

110. Burke LE, Ma J, Azar KM, Bennett GG, Peterson ED, Zheng Y, Riley W, Stephens J, Shah SH, Suffoletto B, Turan TN, Spring B, Steinberger J, Quinn CC, American Heart Association Publications Committee of the Council on Epidemiology and Prevention, Behavior Change Committee of the Council on Cardiometabolic Health, Council on Cardiovascular and Stroke Nursing, Council on Functional Genomics and Translational Biology, Council on Quality of Care and Outcomes Research, and Stroke Council C. Current science on consumer use of Mobile health for cardiovascular disease prevention: a scientific statement from the American Heart Association.

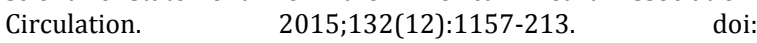
10.1161/CIR.0000000000000232, PMID 26271892.

111. Matzinger P. The danger model: a renewed sense of self. Science. 2002;296(5566):301-5. doi: 10.1126/science.1071059, PMID 11951032.

112. Matzinger P. Tolerance, danger, and the extended family. Annu Rev Immunol. 1994;12:991-1045. doi: 10.1146/annurev.iy.12.040194.005015, PMID 8011301.

113. Akira S, Uematsu S, Takeuchi O. Pathogen recognition and innate immunity. Cell. 2006;124(4):783-801. doi: 10.1016/j.cell.2006.02.015, PMID 16497588.

114. Takeuchi 0, Akira S. Pattern recognition receptors and inflammation. Cell. 2010;140(6):805-20. doi: 10.1016/j.cell.2010.01.022, PMID 20303872.

115. Schroder K, Tschopp J. The inflammasomes. Cell. 2010;140(6):821-32. doi: 10.1016/j.cell.2010.01.040, PMID 20303873.

116. McCarthy CG, Goulopoulou S, Wenceslau CF, Spitler K, Matsumoto T, Webb RC. Toll-like receptors and damageassociated molecular patterns: novel links between inflammation and hypertension. Am J Physiol Heart Circ Physiol. 2014;306(2):H184-96. doi: 10.1152/ ajpheart.00328.2013, PMID 24163075.

117. Kelley N, Jeltema D, Duan Y, He Y. The NLRP3 inflammasome: an overview of mechanisms of activation and regulation. Int J Mol Sci. 2019;20(13):3328. doi: 10.3390/ijms20133328, PMID 31284572.

118. Serbina NV, Jia T, Hohl TM, Pamer EG. Monocyte-mediated defense against microbial pathogens. Annu Rev Immunol. 2008;26:421-52. doi: 10.1146/annurev.immunol.26.021607. 090326, PMID 18303997.

119. Olsen F. Transfer of arterial hypertension by splenic cells from DOCA-salt hypertensive and renal hypertensive rats to normotensive recipients. Acta Pathol Microbiol Scand C. 1980;88(1):1-5. doi: 10.1111/j.1699-0463.1980.tb00065.x, PMID 7376880.

120. Rosales C. Neutrophil: a cell with many roles in inflammation or several cell types? Front Physiol. 2018;9:113. doi: 10.3389/fphys.2018.00113, PMID 29515456.

121. Nicholls SJ, Hazen SL. Myeloperoxidase and cardiovascular disease. Arterioscler Thromb Vasc Biol. 2005;25(6):1102-11. doi: 10.1161/01.ATV.0000163262.83456.6d, PMID 15790935.

122. Zhang C, Reiter C, Eiserich JP, Boersma B, Parks DA, Beckman JS, Barnes S, Kirk M, Baldus S, Darley-Usmar VM, White CR. Larginine chlorination products inhibit endothelial nitric oxide production. J Biol Chem. 2001;276(29):27159-65. doi: 10.1074/jbc.M100191200, PMID 11375389.

123. Marsche G, Heller R, Fauler G, Kovacevic A, Nuszkowski A, Graier W, Sattler W, Malle E. 2-chlorohexadecanal derived from hypochlorite-modified high-density lipoprotein-associated plasmalogen is a natural inhibitor of endothelial nitric oxide biosynthesis. Arterioscler Thromb Vasc Biol. 2004;24(12):2302-6. doi: 10.1161/01.ATV.0000148703.43429.25, PMID 15514213.

124. Auchere F, Capeillère Blandin C. NADPH as a co-substrate for studies of the chlorinating activity of myeloperoxidase. Biochem J. 1999;343(3):603-13. doi: 10.1042/bj3430603, PMID 10527939.

125. Eiserich JP, Baldus S, Brennan ML, Ma W, Zhang C, Tousson A, Castro L, Lusis AJ, Nauseef WM, White CR, Freeman BA. Myeloperoxidase, a leukocyte-derived vascular NO oxidase. Science. 2002;296(5577):2391-4. 10.1126/science.1106830, PMID 12089442.

126. Rudolph TK, Wipper S, Reiter B, Rudolph V, Coym A, Detter C, Lau D, Klinke A, Friedrichs K, Rau T, Pekarova M, Russ D, Knöll $\mathrm{K}$, Kolk M, Schroeder B, Wegscheider K, Andresen H, Schwedhelm E, Boeger R, Ehmke H, Baldus S. Myeloperoxidase deficiency preserves vasomotor function in humans. Eur Heart J. 2012;33(13):1625-34. doi: 10.1093/eurheartj/ehr193, PMID 21724624 .

127. Collin M, Bigley V. Human dendritic cell subsets: an update. Immunology. 2018;154(1):3-20. doi: 10.1111/imm.12888, PMID 29313948.

128. Hevia D, Araos P, Prado C, Fuentes Luppichini E, Rojas M, Alzamora R, Cifuentes-Araneda F, Gonzalez AA, Amador CA, Pacheco R, Michea L. Myeloid CD11c+ antigen-presenting cells ablation prevents hypertension in response to angiotensin II plus high-salt diet. Hypertension. 2018;71(4):709-18. doi: 10.1161/hypertensionaha.117.10145. PMID 29378857.

129. Lu X, Rudemiller NP, Privratsky JR, Ren J, Wen Y, Griffiths R, Crowley SD. Classical dendritic cells mediate hypertension by promoting renal oxidative stress and fluid retention Hypertension. 2020;75(1):131-8. doi: 10.1161/hypertensionaha.119.13667, PMID 31786985.

130. Nahmod K, Gentilini C, Vermeulen M, Uharek L, Wang Y, Zhang J, Schultheiss HP, Geffner J, Walther T. Impaired function of dendritic cells deficient in angiotensin II type 1 receptors. J Pharmacol Exp Ther. 2010;334(3):854-62. doi: 10.1124/jpet.109.161760, PMID 20516139.

131. Vinh A, Chen W, Blinder Y, Weiss D, Taylor WR, Goronzy JJ, Weyand CM, Harrison DG, Guzik TJ. Inhibition and genetic ablation of the B7/CD28 T-cell costimulation axis prevents experimental hypertension. Circulation. 2010;122(24):252937. doi: 10.1161/circulationaha.109.930446, PMID 21126972.

132. Itani HA, Xiao L, Saleh MA, Wu J, Pilkinton MA, Dale BL, Barbaro NR, Foss JD, Kirabo A, Montaniel KR, Norlander AE, Chen W, Sato R, Navar LG, Mallal SA, Madhur MS, Bernstein KE, Harrison DG. CD70 exacerbates blood pressure elevation and renal damage in response to repeated hypertensive stimuli. Circ Res. 2016;118(8):1233-43. doi: 10.1161/CIRCRESAHA.115.308111, PMID 26988069.

133. Herrada AA, Contreras FJ, Marini NP, Amador CA, Gonzalez PA, Cortes CM, Riedel CA, Carvajal CA, Figueroa F, Michea LF, Fardella CE, Kalergis AM. Aldosterone promotes autoimmune damage by enhancing Th17-mediated immunity. J Immunol. 2010;184(1):191-202. doi: 10.4049/jimmunol.0802886, PMID 19949098.

134. Lu X, Rudemiller NP, Wen Y, Ren J, Hammer GE, Griffiths R, Privratsky JR, Yang B, Sparks MA, Crowley SD. A20 in myeloid cells protects against hypertension by inhibiting dendritic cellmediated T-cell activation. Circ Res. 2019;125(12):1055-66. doi: 10.1161/circresaha.119.315343, PMID 31630621.

135. Tsay GJ, Zouali M. The interplay between innate-like B cells and other cell types in autoimmunity. Front Immunol. 2018;9:1064. doi: 10.3389/fimmu.2018.01064, PMID 29868023.

136. Kabelitz D. Expression and function of toll-like receptors in $\mathrm{T}$ lymphocytes. Curr Opin Immunol. 2007;19(1):39-45. doi: 10.1016/j.coi.2006.11.007, PMID 17129718.

137. Svendsen UG. Evidence for an initial, thymus independent and a chronic, thymus dependent phase of DOCA and salt hypertension in mice. Acta Pathol Microbiol Scand A. 1976;84(6):523-8. doi: 10.1111/j.1699-0463.1976.tb00150.x, PMID 998251.

138. Horan MJ, Lovenberg W. Genetic rat models for hypertension: guidelines for breeding, care and use. J Hypertens Suppl. 1986;4(3):S7-9. PMID 3465916.

139. Svendsen UG. Spontaneous hypertension and hypertensive vascular disease in the NZB strain of mice. Acta Pathol 
Microbiol Scand A. 1977;85(4):548-54. doi: 10.1111/j.16990463.1977.tb03887.x, PMID 899791.

140. Svendsen UG. The importance of thymus in the pathogenesis of the chronic phase of hypertension in mice following partial infarction of the kidney. Acta Pathol Microbiol Scand A. 1977;85(4):539-47. doi: 10.1111/j.1699-0463.1977.tb03886.x, PMID 331861.

141. Bataillard A, Vincent M, Sassard J, Touraine JL. Antihypertensive effect of an immunosuppressive agent, cyclophosphamide, in genetically hypertensive rats of the Lyon strain. Int J Immunopharmacol. 1989;11(4):377-84. doi: 10.1016/0192-0561(89)90084-2, PMID 2777432.

142. Norman RA, Jr, Galloway PG, Dzielak DJ, Huang M. Mechanisms of partial renal infarct hypertension. J Hypertens. 1988;6(5):397-403. doi: 10.1097/00004872-19880500000010 , PMID 3385205.

143. Okuda T, Grollman A. Passive transfer of autoimmune induced hypertension in the rat by lymph node cells. Tex Rep Biol Med. 1967;25(2):257-64. PMID 6040652.
144. Suryaprabha P, Padma T, Rao UB. Increased serum IgG levels in essential hypertension. Immunol Lett. 1984;8(3):143-5. doi: 10.1016/0165-2478(84)90067-1, PMID 6500633.

145. Hilme E, Herlitz H, Soderstrom T, Hansson L. Increased secretion of immunoglobulins in malignant hypertension. J Hypertens. 1989;7(2):91-5. doi: 10.1097/00004872198902000-00003, PMID 2647845.

146. Chan CT, Sobey CG, Lieu M, Ferens D, Kett MM, Diep H, Kim HA, Krishnan SM, Lewis CV, Salimova E, Tipping P, Vinh A, Samuel CS, Peter K, Guzik TJ, Kyaw TS, Toh BH, Bobik A, Drummond GR. Obligatory role for B cells in the development of angiotensin II-dependent hypertension. Hypertension. 2015;66(5):1023-33. doi 10.1161/HYPERTENSIONAHA.115.05779, PMID 26351030.

147. Taylor EB, Barati MT, Powell DW, Turbeville HR, Ryan MJ. Plasma cell depletion attenuates hypertension in an experimental model of autoimmune disease. Hypertension 2018;71(4):719-28. 